\title{
Quality Assessment of Surface Waters and Sediments of Anya-Ogologo River
}

\author{
Okoroafor Isaiah $^{1}$, Charles Obunwo ${ }^{1}$, Ndokiari Boisa ${ }^{1}$, Owhonda Ihunwo ${ }^{2, *}$ \\ ${ }^{1}$ Department of Chemical Sciences, Rivers State University, Port Harcourt, Nigeria \\ ${ }^{2}$ Niger Delate Aqua Research Group (NDARG), Department of Biochemistry and Chemistry Technology, School of Science Laboratory \\ Technology (SSLT), University of Port Harcourt, Port Harcourt, Nigeria
}

\section{Email address:}

isaiah.okoroafor1@ust.edu.ng (O. Isaiah), obunwo.charles@ust.edu.ng (C. Obunwo), ndokiari.boisa@ust.edu.ng (N. Boisa), owhonda.ihunwo@hotmail.co.uk (O. Ihunwo)

${ }^{*}$ Corresponding author

\section{To cite this article:}

Okoroafor Isaiah, Charles Obunwo, Ndokiari Boisa, Owhonda Ihunwo. Quality Assessment of Surface Waters and Sediments of Anya-Ogologo River. Journal of Water Resources and Ocean Science. Vol. 8, No. 5, 2019, pp. 77-85. doi: 10.11648/j.wros.20190805.13

Received: May 26, 2019; Accepted: October 21, 2019; Published: October 25, 2019

\begin{abstract}
This study evaluated physical and chemical properties and calculated the Water Quality Index of the Anya Ogologo River in Rivers State, Nigeria. Four stations along the river were identified for this study based on accessibility and activities taking place on the river bank. Water and sediment sample collection were conducted once a week every month spanning a period of four months (February - May). In-situ measurements of surface water were taken for the following parameters: $\mathrm{pH}$, salinity, electric conductivity, total dissolved solids, dissolved oxygen and temperature. Surface water was collected from each station to the laboratory and analysed for phosphate, nitrate sulphate, biochemical oxygen demand, and metals (lead, cadmium, manganese and copper). The parameters studied showed variations across stations. Sediment samples indicated the presence of manganese and copper metals. The WQI values observed were as follows; station 1: 55.07\%, station 2: $43.58 \%$, station 3: $56.29 \%$ and station $4: 67.10 \%$. This indicates that generally the river is unsuitable for drinking, swimming, irrigation particularly.
\end{abstract}

Keywords: Anthropogenic, Physicochemical, Pollution, Urban, Water Quality

\section{Introduction}

A River is a naturally occurring resource that plays an important role in the biosphere because of their abundant uses. The Earth's surface is covered $70 \%$ by water, but only $3 \%$ of it is freshwater, distributed in aquifers, polar ice caps, rivers, lakes and other reserves such as clouds and steam; $97 \%$ is saltwater. They are used by humans for transportation, fishing, hydropower and domestic, industrial agricultural water supplies [1]. The preservation of a healthy aquatic ecosystem depends mainly on the physicochemical properties and biological diversity [2]. Water is important for natural ecosystems and human development. It is important for various activities such as drinking, cooking, industry, agriculture, and recreation. In the human body, it is also used to transport, dissolve organic matter and add nutrients while carrying waste materials, regulates body temperature and reduces dehydration [3]. The importance of rivers cannot be overemphasized, and for this reason, they should be monitored to assess their "health" or "status".

River water quality can be affected by the activities on the watershed, geology of the watershed, riparian zone vegetation and interaction between dry and wet interphase which contributes to nutrient input in the river [4-6]. The increase in human population has been identified as a stressor to the natural environment, this is because, to accommodate the increasing human population, changes in the natural environment is will occur. Conversion of undeveloped expanses of land into urban areas can lead to changes in the natural topography which can change the spatial and temporal dynamics the environmental. New constructions such as buildings and bridges can alter the natural precipitation infiltration percolation and runoff, this can change natural boundaries and drainages in the catchment area [7].

Water quality index is one of the most effective tools to communicate information on the quality of water. It is an important parameter for the assessment and management of 
surface water. It provides up-to-date information about the concentration of various solutes in a place and time. The quality parameters provide a yardstick for assessing the nature of water for designated use and to improve the existing condition [8]. Water Quality Index (WQI) can be useful for decision-makers in assessment and classification rivers [9]. In regions with limited surface water resource, it can play an essential role in assigning use for waters, understanding the level of pollution in water and creating management tools to mitigate pollution where necessary. The quality of water is directly related to the physical and chemical parameters of the water. It is also important to note that these parameters can vary from season and location (i.e. temporally and spatially) $[10,11]$. Hence the importance to study these parameters in a wholistic matter i.e. WQI.

In a study carried out in Dende and Bengo Rivers in Angola, they aimed to evaluate the water quality (physicochemical and microbiological parameters) of three Angolan rivers (Kwanza, Bengo and Dande) in locations where water is used as drinking water or abstracted for human consumption. Their results indicated that in dry season the water was suitable for the purpose while in wet season the water was unsuitable for that purpose (high levels of faecal coliforms were detected) [12]. In another study, observations were carried out in the surface waters of Saraydüzü Dam Lake within Sinop provincial borders for 1 year to determine water quality. The basic 28 variables used to determine water quality were measured monthly at six stations. Taking into account the World Health Organization's drinking water standards, the water quality index (WQI) and Turkey's Ministry of Forestry and Water Affairs Surface Water Quality Regulations (SWQR) were used in determining the water quality. Water quality parameters did not exceed the recommended limit values in all months and at all stations. According to these values, the Saraydüzü Dam Lake water belongs to the 'very good' class in terms of drinking water quality [13]. Between March and December 2002, a study assessed the quality and pollution status of source surface waters in Zaria, Nigeria by monitoring the nature, cause and extent of pollution in Samaru stream, Kubanni River and Kubanni dam [14]. Their results showed that the main pollution sources to the river were municipal wastewater, stormwater runoffs, the ABU sewage treatment plant, abattoir effluents and irrigation farms treated with chemical fertilisers.

The Anya Ogologo River is exceptionally important to the inhabitants of Mgbuosimini community, but due to the numerous human activities in the area such as dredging, drainage constructions, waste disposal, and burning, building construction, and agriculture, this river is also susceptible to the pollution that comes about due to the above-mentioned activities. This study aims to 1) determine levels of some physiochemical parameters in surface water and sediment of Anya-Ogologo River, 2) determine levels of heavy metals (lead, copper, cadmium and manganese) in surface water and sediment, 3) determine the level of the microbial activities by assessing THB, TCB and FCB in surface water of the Rive, 4) compare levels of measured parameters with Standard Permissible Limits and 5) calculate the Water Quality Index for each sample station along the river.

\section{Materials and Methods}

\subsection{Description of the Study Area}

The study was carried out on a headwater stream of the Anya-Ogologo River in Mgbuosimini Community of Port Harcourt, Rivers State Nigeria. The community covers a land area of about $4.2 \mathrm{~km}^{2}$ and the length of our study path on the river stretches to about $1.14 \mathrm{~km}$, with an average elevation of $4 \mathrm{~m}$ and an average slope of $0.8 \%$. The local people use the river for fishing, washing and other municipal activities. The river headwater runs behind the community into which urban drainage empties, there is also evidence of dumping of waste products from homes. The Anya-Ogologo River plays host to a fish market which is important to the community and fish farming and marketing are part of the culture of the people.

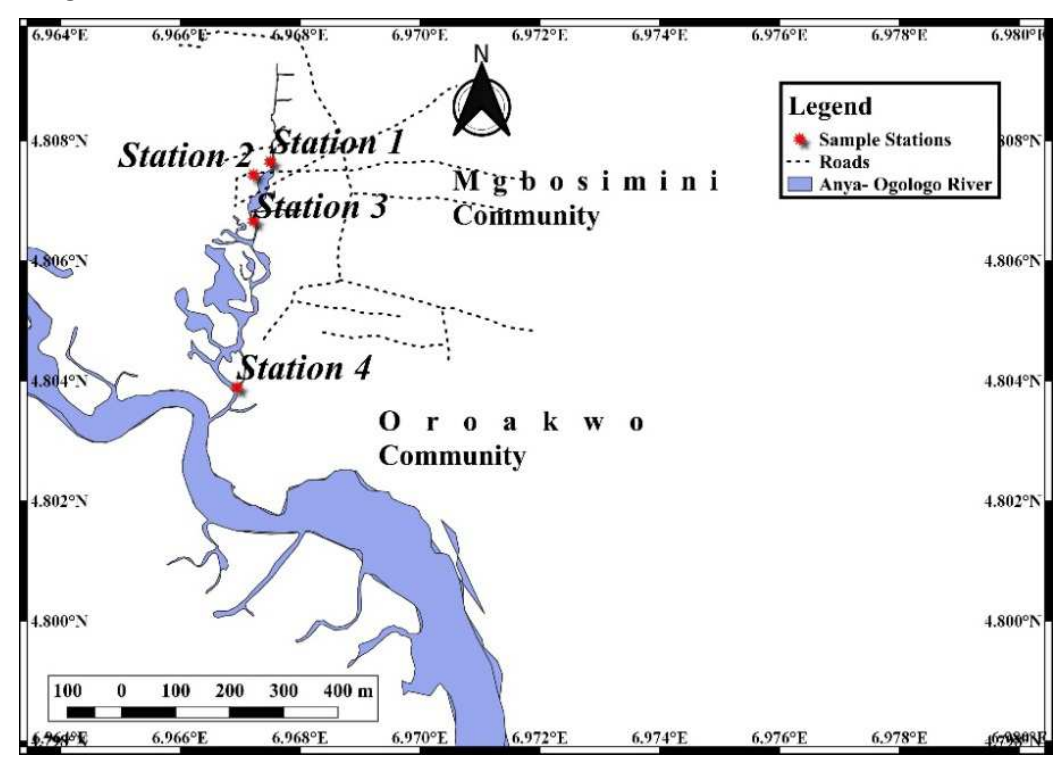

Figure 1. Study area map. 
The sampling stations were selected using a Geographic Positioning System (GPS) tool, and 4 sampling stations were initially identified. the choices of sample points were based on accessibility to the study river. Water and sediment samples were collected from each station once every week for four months from February to the end of May 2018. Five samples were collected at each sample station and mixed together to make a composite sample, Station 1: $4^{\circ} 48^{\prime} 27.6^{\prime \prime} \mathrm{N}$ $6^{\circ} 58^{\prime} 03.0^{\prime \prime E}$, Station 2: 448'26.8"N 658'02.0"E, Station 3: $4^{\circ} 48^{\prime} 24.0^{\prime \prime} \mathrm{N} \quad 6^{\circ} 58^{\prime} 02.0^{\prime \prime} \mathrm{E}, \quad$ Station $4: \quad 4^{\circ} 48^{\prime} 14.0^{\prime \prime} \mathrm{N}$ $6^{\circ} 58^{\prime} 01.0 " \mathrm{E}$ (Figure 1).

\subsection{Sample Collection and Analysis}

In-situ measurements were taken for DO, turbidity, TDS, salinity, temperature, conductivity and $\mathrm{pH}$ with a meter. The $\mathrm{BOD}_{5}$ was calculated by deducting the DO after five days of incubation from the DO measurement on a collection of samples at the same point in $\mathrm{mg} / \mathrm{L}$ and multiplying by the volume of sample incubated [15]. Reagents used for the analysis of nitrate were; nitrate-free water, stock nitrate solution, intermediate nitrate solution and hydrochloric acid solution [16]. The Stannous Chloride Method was used for phosphate ion measurement [17]. The metals $(\mathrm{Pb}, \mathrm{Cd}, \mathrm{Cu}$ and $\mathrm{Mn})$ were analysed using Atomic Absorption Spectrophotometer [18]. Membrane Filtration Method was used to determine Total Coliform Bacteria and Faecal
Coliform Bacteria [19]. Was used to determine Total Heterotrophic Bacteria [20].

\subsection{Data Analysis}

Statistical analysis of variance (ANOVA) was used to compare the variation in spatial and temporal data for water and sediment using Sigma Plot package (Version 14.0) [21].

Water quality index (WQI) is defined as a technique of rating that provides the composite influence of individual water quality parameter on the overall quality of water [22]. The quality rating scale for each parameter $\mathrm{q}_{\mathrm{i}}$ was calculated by using this expression:

$$
\mathrm{q}_{\mathrm{i}}=\left(\frac{\mathrm{C}_{\mathrm{i}}}{\mathrm{s}_{\mathrm{i}}}\right) \times 100
$$

Where $C_{i}$ is the parameter concentration and $S_{i}$ respective standard.

Unit weight $\left(\mathrm{W}_{\mathrm{i}}\right)$ was calculated by a value inversely proportional to the recommended standard $\left(\mathrm{S}_{\mathrm{i}}\right)$ of the corresponding parameter (Table 1):

$$
\mathrm{W}_{\mathrm{i}}=\frac{1}{\mathrm{~S}_{\mathrm{i}}}
$$

The WQI was then calculated as follows:

$$
\text { Overall WQI }=\sum \mathrm{q}_{\mathrm{i}} \mathrm{W}_{\mathrm{i}} / \sum \mathrm{W}_{\mathrm{i}}
$$

Table 1. Relative weights $\left(W_{i}\right)$ of the parameters and used for WQI determination.

\begin{tabular}{llll}
\hline Parameter & Unit & Water Quality Standard & Unit Weight (Wi) \\
\hline Electric Conductivity & $\mu \mathrm{s} / \mathrm{cm}$ & 1000 & 0.001 \\
$\mathrm{pH}$ & & $6.5-8.5$ & 0.13 \\
Dissolved Oxygen & $\mathrm{mg} / \mathrm{l}$ & 5 & 0.2 \\
Total Dissolved Oxygen & $\mathrm{mg} / \mathrm{l}$ & 500 & 0.002 \\
Biological Oxygen Demand & $\mathrm{mg} / \mathrm{l}$ & 5 & 0.2 \\
Nitrate & $\mathrm{mg} / \mathrm{l}$ & 45 & 0.022 \\
Sulphate & $\mathrm{mg} / \mathrm{l}$ & 150 & 0.007 \\
\hline
\end{tabular}

Water Quality Standard [23]

Table 2. WQI range, status and possible usage of the water sample.

\begin{tabular}{lll}
\hline WQI & Water quality status (WQS) & Possible usage \\
\hline $0-25$ & Excellent & Drinking, Irrigation and Industrial \\
$26-50$ & Poor & Drinking, Irrigation and Industrial \\
$51-75$ & Very Poor & Drinking, Irrigation and Industrial \\
Above 100 & Unsuitable for drinking and fish culture & Proper treatment required before use \\
\hline
\end{tabular}

[24]

\section{Results and Discussion}

\subsection{Physical and Chemical Parameters}

$\mathrm{pH}$ varied in mean values of $6.52 \pm 0.45$ as maximum $6.29 \pm 0.15$ as a minimum for station 3 and station 2 respectively (Figure 2A \& 3A). After the statistical variance was calculated, it showed no significant difference from station 1 to station 4 in water and sediment $(p>0.05)$. The variation in $\mathrm{pH}$ could be as a result of climate change, infiltration of $\mathrm{CO}_{2}$ into the river and its removal through photosynthesis $\mathrm{pH}$ values during different season of the year were also attributed to factors like removal of $\mathrm{CO}_{2}$ by photosynthesis through bicarbonate degradation, dilution of waste with freshwater, reduction of temperature, and decomposition of organic matter [25]. This is supported by a previous study carried out by [26]. The analysis results gave values of salinity ranging from $0.22 \pm 0.04 \mathrm{ppt}$ at station 1 to $2.75 \pm 0.88 \mathrm{ppt}$ at station 4 (Figure $2 \mathrm{~B} \& 3 \mathrm{~B}$ ). EC values ranged from $438 \pm 86.49 \mu \mathrm{s} / \mathrm{cm}$ (lowest) in station 1 to $4793.5 \pm 1394.324 \mu \mathrm{s} / \mathrm{cm}$ in station 4 (highest) (Figure $2 \mathrm{C} \&$ $3 \mathrm{C})$. High values of $\mathrm{EC}$ show that a large number of ionic 
substances are present in water [27]. Station 3 and station 4 having noticeably high values for electric conductivity mainly because of the dumpsite burning at station 3 and brackish water at station 4 .

The amount of dissolved oxygen in a pristine freshwater usually range from $7.56 \mathrm{mg} / 1$ at $30^{\circ} \mathrm{C}$ to $14.62 \mathrm{mg} / 1$ at $0^{\circ} \mathrm{C}$ [28]. Research has shown that the quantity of oxygen in a river is directly proportional to the water quality index of a river [29]. Impurities such as dissolved minerals reduce the quantity of oxygen that dissolves in water. Dissolved oxygen enters the water by diffusion from the atmosphere. When water is mixed with air as it falls over rocks and waterfalls, the level of DO is greatly increased. The result of the analysis showed DO values that ranged from $0.75 \pm 0.9 \mathrm{mg} / \mathrm{l}$ in station 2 to $2.55 \pm 1.1 \mathrm{mg} / 1$ in station 4 (Figure $2 \mathrm{D}$ ), the high values recorded can be attributed to the fast-flowing nature of the river at station 4. Mean values of biochemical oxygen demand in the river showed a statistically significant difference $(p<0.001)$ from station 1 to station 4 . BOD is a measure of microbial activities that consume dissolved oxygen in the water. Water temperature in all stations was measured during the sample collection. The river temperature varied from $30.30 \pm 0.83^{\circ} \mathrm{C}$ in station 1 to $31.73 \pm 1.02^{\circ} \mathrm{C}$ in station 2 , (upstream) and from $31.18 \pm 1.08^{\circ} \mathrm{C}$ in station 3 to $30.90 \pm 1.09^{\circ} \mathrm{C}$ in station 4 (downstream) (Figure 2E). ANOVA analysis between stations showed no significant difference in values $(p>0.05)$. Primary sources for higher TDS in the river water might be due to the discharge of domestic waste, discharge of sewage and other human activities like washing clothes with detergent, parking vehicles near the river. The river flow rate and volume also play a part in the level of total dissolved solids that are present at the station on the river. Murhekar, (2011) also reported similar TDS values (221 to $3534 \mathrm{mg} / \mathrm{l}$ ) for river water (Figure 2F). Statistical analysis of variance gave results showing no statistically significant difference $(p>0.05)$ across the river.

Phosphorus is essential for the growth of aquatic plants in a stream. However, at certain concentrations, phosphate encourages the growth of eutrophication in rivers [5]. Research has shown that phosphate increase in a fluvial system can be attributed to discharge from both urban, such as wastewater and sewage effluent and agricultural sources from phosphorus-enriched soil [5]. Mean values of phosphate were higher in station 3 cross the river (Figure $2 \mathrm{H}$ ). Nitrate occurs naturally in aquatic systems; aquatic organisms add to

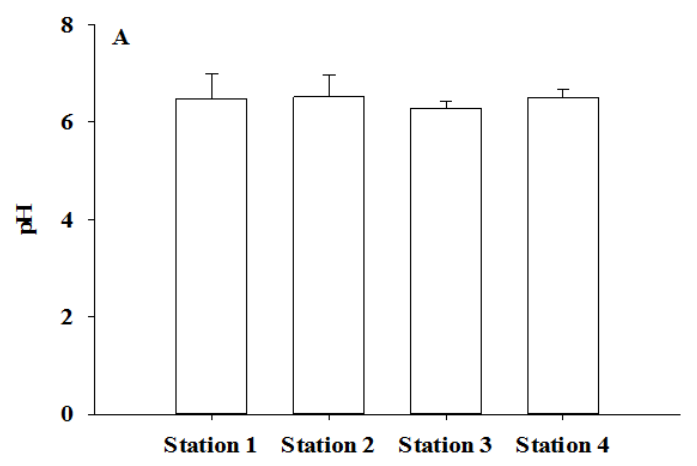

the concentration of nitrate in a river by excreting waste high in ammonia which is then converted to nitrate and further to nitrite by certain microbial species. Nitrate, similar to phosphate, in excess can lead to a eutrophic condition in a river. Eutrophication can also lead to a reduction in the quantity of dissolved oxygen is present in the river, in turn reducing the rate of conversion of ammonia to nitrite and to nitrate, leaving a high concentration of nitrite and ammonia, which are more toxic in the river [31]. The reduction in the quantity of dissolved oxygen in the river can lead to an inhabitable condition for aquatic lives. Mean values of nitrate were highest in station $2(12.10 \pm 9.99 \mathrm{mg} / \mathrm{l})$ and lowest in station $1(3.78 \pm 4.04 \mathrm{mg} / \mathrm{l})$ (Figure 2I). The concentration of nitrate in this study river was similar, those slightly higher, to those in River Ona and River Alaro which ranged between 3.00-8.55 [32].

Metals studied in this research include: Manganese (Mn), Cadmium $(\mathrm{Cd})$, Copper $(\mathrm{Cu})$ and Lead $(\mathrm{Pb})$. Although $\mathrm{Cd}$ and $\mathrm{Pb}$ were not detected in either water or sediment in the study river, $\mathrm{Mn}$ and $\mathrm{Cu}$ were detected in the river. The concentrations of the detected metals were higher in the sediment than in the water (Figure 3D \& 3E). Metal concentrations in the surface water were lower than those measured in a tropical manmade lake Southwestern Nigeria [33]. Similarly, the metal concentrations were also lower than those measured in River Balogun which had metal concentrations higher than WHO standards [34].

Faecal coliform bacteria are a collection of relatively harmless microorganisms that live in large number in the intestines of the warm and cold-blooded animals [35]. Escherichia coli (commonly called E. Coli), is the most common species of this group os bacteria. Their presence in surface water indicates the presence of faecal waste entering the water from human beings and other warm-blooded animals [35]. There were high microbial activities observed in this river. Results showed variations of bacterial activities from station 1 to station 4 (Figure 2L, 2M \&2N). This decline of microbial population and activity from up to downstream could be as a result of the increase in salinity from station 1 to station 4 [36]. The microbial count in the study river is higher than those measured in Zamfara state [14]. In the assessment of the quality of water from hand-dug wells in ghana, Total coliform and Escherichia coli were below the minimum detection limit (MDL) of 20 MPN per $100 \mathrm{ml}$ in all the samples which were lower than those in the present study [37].

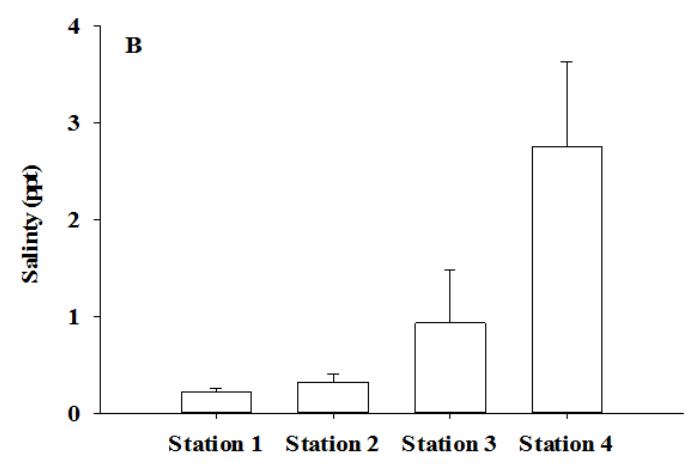



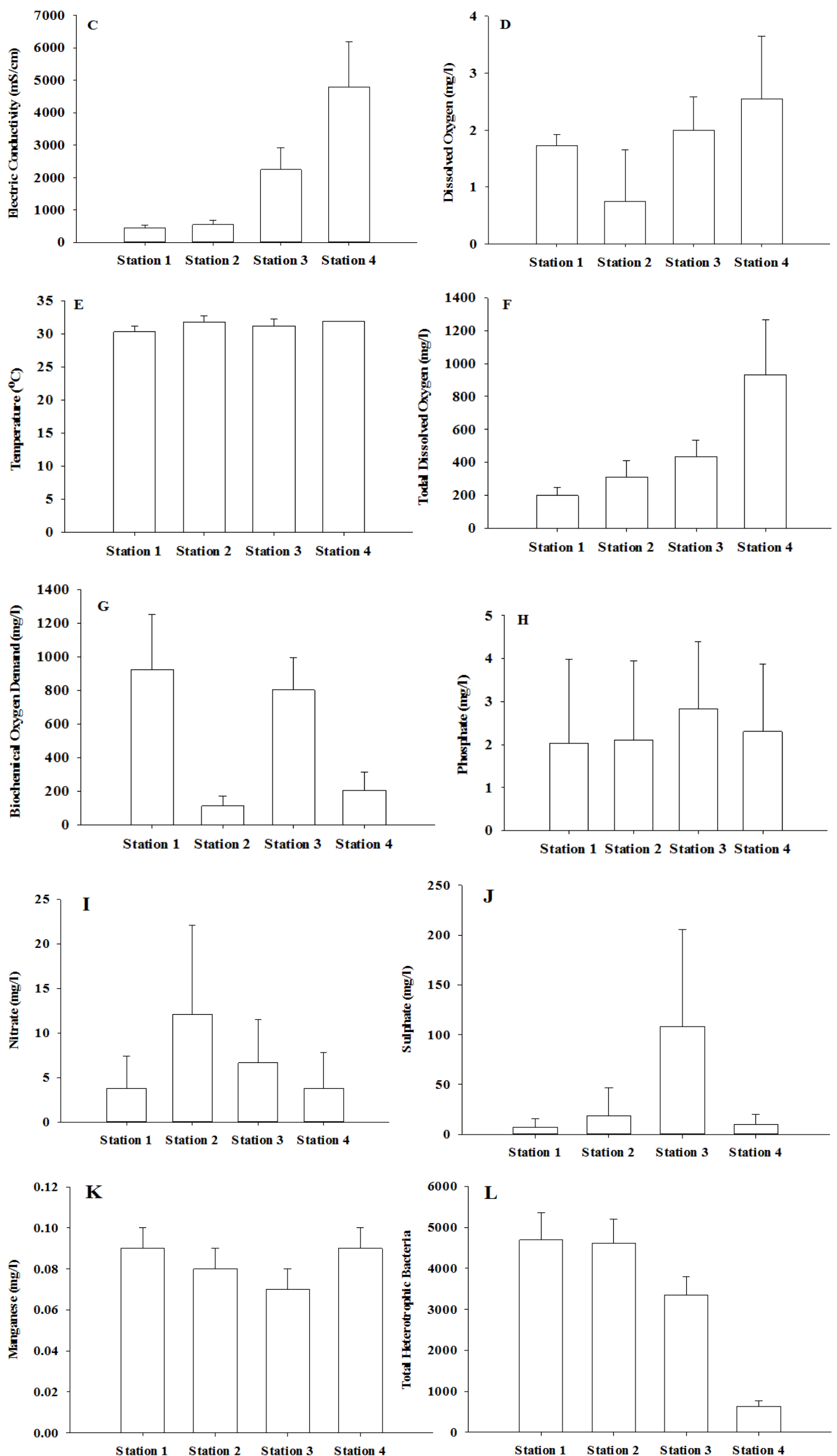


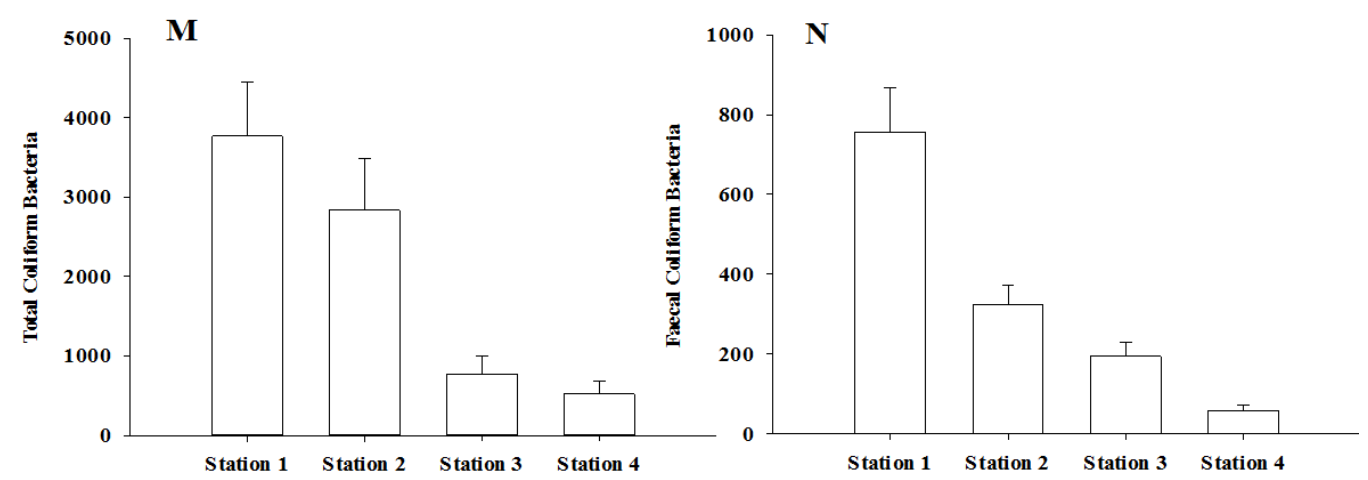

Figure 2. Spatial distribution of surface water parameters of Anya-Ogologo River. A-pH, B-Salinity, C-Electric Conductivity, D-Dissolved Oxygen, ETemperature, F-Total Dissolved Oxygen, G-Biochemical Oxygen Demand, H-Phosphate, I-Nitrate, J-Sulphate, K-Manganese, L-Total Heterotrophic Bacteria, M-Total Coliform Bacteria, N-Feacal Coliform Bacteria.
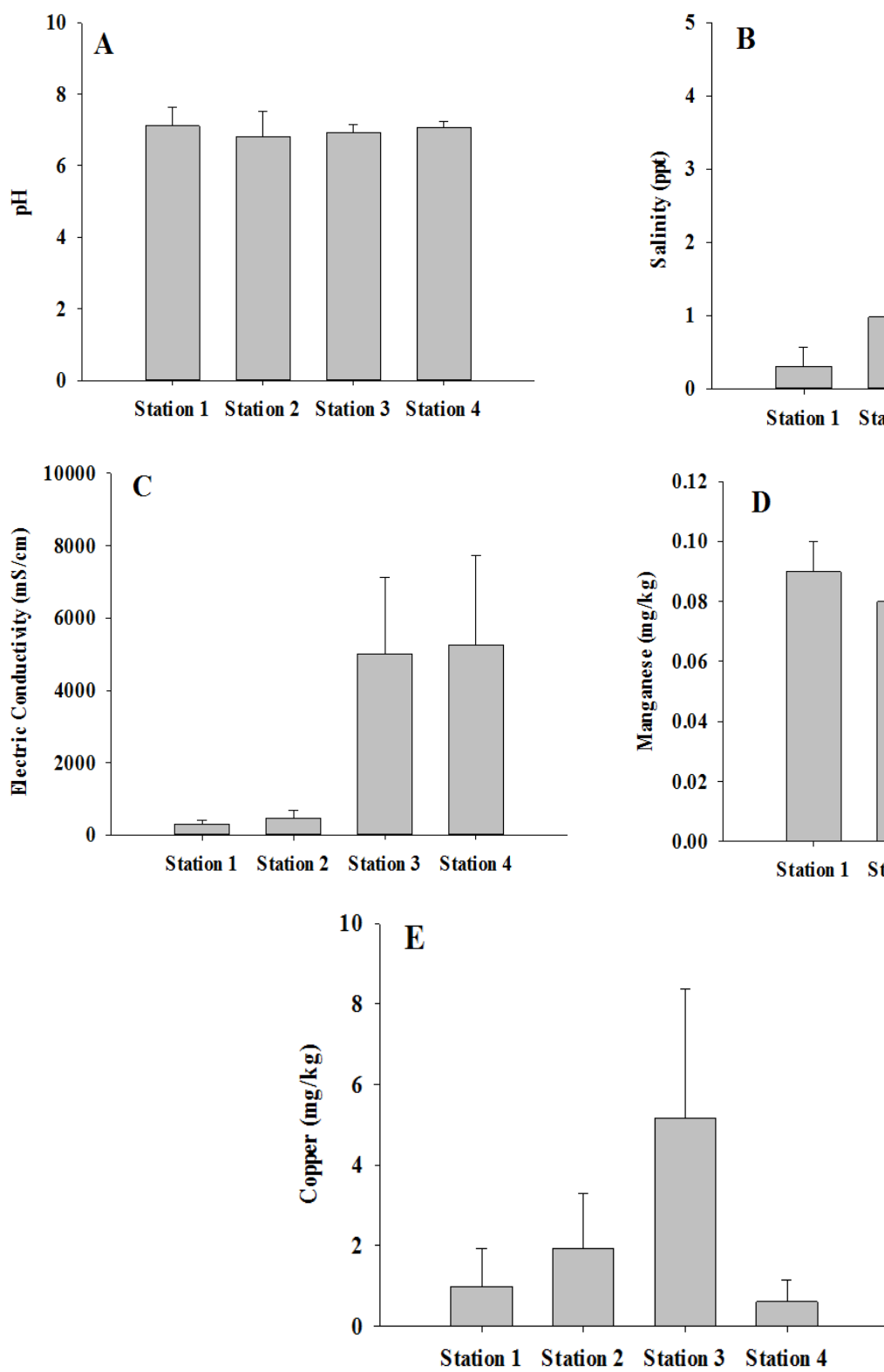
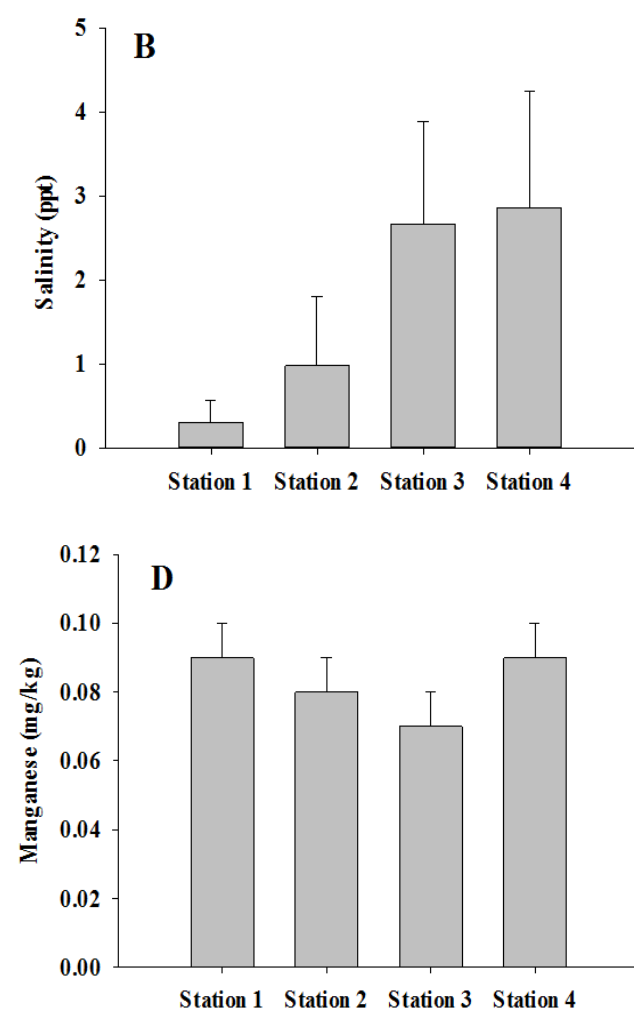


\subsection{Water Quality Assessment}

As stated earlier, WQI is designed to combine multiple parameters in a river in order to give a holistic view of the river and quantify the level of cleanliness of pollution. In the present study, EC, $\mathrm{pH}$, TDS, DO, Sulphate and Nitrate were used to assess the WQI. WQI ranged from 41.87 62.40 (Table 3). The WQI very poor, however, it can be used for irrigation and industry. Despite the high WQI measured in this study river, they were lower than those measured in River Ravi at Madhopur (India) [38]. WQI from the different sampling stations in the Niger Delta were found to be varied from 34.80 to 36.26 for pipe-borne water, 38.52 to 48.67 for borehole water and 55.05 to 84.94 for stream water [39]. This present study calls within the range for stream water.

Table 3. Water quality index for Anya-Ogologo River.

\begin{tabular}{|c|c|c|c|c|c|}
\hline Parameter & Observed Values $C_{i}$ & Standard Value Si & Unit Weight Wi & Quality Rating qi & $\mathbf{q}_{\mathrm{i}} \mathbf{w}_{\mathrm{i}}$ \\
\hline \multicolumn{6}{|l|}{ Station 1} \\
\hline Electrical Conductivity & 438 & 1000 & 0.001 & 43.8 & 0.0044 \\
\hline $\mathrm{pH}$ & 6.49 & 7.5 & 0.13 & 86.5 & 11.245 \\
\hline Total Dissolved Solids & 199.5 & 500 & 0.002 & 39.9 & 0.0798 \\
\hline Dissolved Oxygen & 1.73 & 5 & 0.2 & 34.6 & 6.92 \\
\hline Nitrate & 3.8 & 45 & 0.022 & 8.4 & 0.1848 \\
\hline Sulphate & 7.05 & 150 & 0.007 & 4.7 & 0.0329 \\
\hline WQI & 51.01 & & & & \\
\hline \multicolumn{6}{|l|}{ Station 2} \\
\hline Electrical Conductivity & 546 & 1000 & 0.001 & 54.6 & 0.0546 \\
\hline $\mathrm{pH}$ & 6.52 & 7.5 & 0.13 & 86.93 & 11.301 \\
\hline Total Dissolved Solids & 312.25 & 500 & 0.002 & 62.45 & 0.1249 \\
\hline Dissolved Oxygen & 0.75 & 5 & 0.2 & 15 & 3 \\
\hline Nitrate & 12.1 & 45 & 0.022 & 26.89 & 0.5916 \\
\hline Sulphate & 18.48 & 150 & 0.007 & 12.32 & 0.0863 \\
\hline WQI & 41.87 & & & & \\
\hline \multicolumn{6}{|l|}{ Station 3} \\
\hline Electrical Conductivity & 2242.5 & 1000 & 0.001 & 224.25 & 0.2243 \\
\hline $\mathrm{pH}$ & 6.29 & 7.5 & 0.13 & 83.87 & 10.903 \\
\hline Total Dissolved Solids & 433 & 500 & 0.002 & 86.6 & 0.1732 \\
\hline Dissolved Oxygen & 2 & 5 & 0.2 & 40 & 8 \\
\hline Nitrate & 6.67 & 45 & 0.022 & 14.8 & 0.3256 \\
\hline Sulphate & 108.48 & 150 & 0.007 & 72.32 & 0.5062 \\
\hline WQI & 55.61 & & & & \\
\hline \multicolumn{6}{|l|}{ Station 4} \\
\hline Electrical Conductivity & 4793.5 & 1000 & 0.001 & 479.35 & 0.4794 \\
\hline $\mathrm{pH}$ & 6.51 & 7.5 & 0.13 & 86.8 & 11.284 \\
\hline Total Dissolved Solids & 931.5 & 500 & 0.002 & 186.3 & 0.3726 \\
\hline Dissolved Oxygen & 2.55 & 5 & 0.2 & 51 & 10.2 \\
\hline Nitrate & 3.78 & 45 & 0.022 & 8.4 & 0.1848 \\
\hline Sulphate & 10.35 & 150 & 0.007 & 6.9 & 0.0483 \\
\hline WQI & 62.4 & & & & \\
\hline
\end{tabular}

\section{Conclusion}

This study assessed the physicochemical parameters and water quality index of the Anya Ogologo river and identified factors that cause changes in different stations on the river and in different seasons. Results show that physical and chemical properties varied spatially and temporally. Although rains are seen to wash off pollutants into the aquatic system, in this study, the coming of the rains diluted the concentrations of the pollutants.

Physical and chemical parameters varied spatially and temporally from station 1 to station 4. Cadmium and lead were below detectable limits in water and sediment, however, manganese was detected in water, while both manganese and copper were identified in the sediment. This confirms that sediment is the sink of contaminants in the aquatic system. However, the microbiology analysis identified very high concentrations of Faecal Coliform Bacteria and Total Coliform Bacteria. Results of WQI scores also show that the general health of the river is unsafe for drinking, irrigation and recreational activities and may potentially pose a threat to aquatic life. Therefore, for this surface water to suitable for use, there is a need for treatment. The concentrations of the pollutants identified in the study can be attributed to the human activities taken place in the catchment area.

\section{Acknowledgements}

The authors appreciate the effort of field and laboratory 
members of staff of Niger Delta Aqua Research Group, specifically; Chinwe Elenga, Mmedorenyin Okon, Chisom Eli Ekpendu and Mmedara Okon, for the successful completion of the project.

\section{References}

[1] J. F. Coles, T. F. Cuffney, G. McMahon, and K. M. Beaulieu, "The Effects of Urbanization on the Biological, Physical, and Chemical Characteristics of Coastal New England Streams," U.S. Geol. Surv. Prof. Pap. 1695, p. 47 p, 2010.

[2] G. V. Venkataraman, P. N. Sandhya Rani, N. S. Raju, S. T. Girisha, and B. V. Raghavendra, "Physico- Chemical Characteristics and Impact of Aquatic Pollutants on the Vital organs of a Freshwater Fish Glossogobius giuris," Research $J$. Environ. Toxicol., vol. 1, no. 1, pp. 1-15, 2007.

[3] V. Jayalakshmi, N. Lakshmi, and M. A. S. Charya, "Assessment of Physico-chemical parameters of water and wastewaters in and around Vijayawada," Int. J. Res. Pharm. Biomed. Sci., vol. 2, no. 3, pp. 1041-1046, 2011.

[4] A.. Hounslow, Water Quality Data. Boca Raton: Boca Raton: CRC Press, 1995.

[5] T. E. Jordan, D. E. Weller, and C. E. Pelc, "Effects of Local Watershed Land Use on Water Quality in Mid-Atlantic Coastal Bays and Subestuaries of the Chesapeake Bay," Estuaries and Coasts, pp. 1-16, 2017.

[6] K. E. Bencala, "2.20 - Stream-Groundwater Interactions,” P. B. T.-T. on W. S. Wilderer, Ed. Oxford: Elsevier, 2011, pp. 537-546.

[7] F. Rodriguez, E. Bocher, and K. Chancibault, "Terrain representation impact on periurban catchment morphological properties," J. Hydrol., vol. 485, pp. 54-67, 2013.

[8] T. Faiza, Y. Risjani, S. Djati, B. Yanuwiadi, and L. Amin, "The analysis of the physical and chemical properties of the water quality in the rainy season in the Sumber Maron river Kepanjen, Malang Indonesia," Sci. World J., vol. 3, no. 12, pp. 34-37, 2012.

[9] C. De La Mora-Orozco, H. Flores-Lopez, H. Rubio-Arias, A. Chavez-Duran, and J. Ochoa-Rivero, "Developing a Water Quality Index (WQI) for an Irrigation Dam.," Int. J. Environ. Res. Public Health, vol. 14, no. 5, Apr. 2017.

[10] R. M. Utz, K. N. Eshleman, and R. H. Hilderbrand, "Variation in physicochemical responses to urbanization in streams between two Mid-Atlantic physiographic regions," Ecol. Appl., vol. 21, no. 2, pp. 402-415, Mar. 2011.

[11] K. Fatema, W. O. Wan Maznah, and M. M. Isa, "Spatial and Temporal Variation of Physico-chemical Parameters in the Merbok Estuary, Kedah, Malaysia," Trop. life Sci. Res., vol. 25, no. 2, pp. 1-19, Dec. 2014.

[12] J. M. Paca, F. M. Santos, J. C. M. Pires, A. A. Leitão, and R. A. R. Boaventura, "Quality assessment of water intended for human consumption from Kwanza, Dande and Bengo rivers (Angola)," Environ. Pollut., vol. 254, p. 113037, 2019.

[13] S. Kükrer and E. Mutlu, "Assessment of surface water quality using water quality index and multivariate statistical analyses in Saraydüzü Dam Lake, Turkey," Environ. Monit. Assess., vol. 191, no. 2 , p. $71,2019$.
[14] V. N. Chigor, V. J. Umoh, C. A. Okuofu, J. B. Ameh, E. O. Igbinosa, and A. I. Okoh, "Water quality assessment: surface water sources used for drinking and irrigation in Zaria, Nigeria are a public health hazard.," Environ. Monit. Assess., vol. 184, no. 5, pp. 3389-3400, May 2012.

[15] S. W. McKenzie and G. C. Delzer, "FIVE-DAY BIOCHEMICAL OXYGEN DEMAND,” vol. 7, pp. 1-21, 2003.

[16] APHA, “4500-NO3-B. Ultraviolet Spectrophotometric Screening Method," in Standard Methods for the Examination of Water and Wastewater, 18th ed., E. G. Arnold, S. C. Lenore, and D. E. Andrew, Eds. New York, NY (United States): American Public Health Association, American Water Works Association, Water Environment Federation, 1992.

[17] AHPA, "Method 4500-P/Stannous Chloride Method," in Standard Methods for the Examination of Water and Wastewater, 18th ed., E. G. Arnold, S. C. Lenore, and D. E. Andrew, Eds. New York, NY (United States): American Public Health Association, American Water Works Association, Water Environment Federation, 1999.

[18] APHA, "3111 Metals by Flame Atomic Absorption Spectrophotometry," in Standard Methods for the Examination of Water and Wastewater, 18th ed., E. G. Arnold, S. C. Lenore, and D. E. Andrew, Eds. New York, NY (United States): American Public Health Association, American Water Works Association, Water Environment Federation, 1992.

[19] Hach Company/ Hach Lang GmbH, "Coliforms, Total, Fecal and E. coli. m-Endo Broth Ampule, Method 8074,” 2017.

[20] Hach Company/ Hach Lang GmbH, "Heterotrophic Bacteria. Plate Count Agar, Method 8241,” 2015.

[21] Systat Software. Inc., "SigmaPlot for windows version 12.5," 2011.

[22] P. Singh, A. Tiwari, and D. M. Mahato, Qualitative Assessment of Surface Water of West Bokaro Coalfield, Jharkhand by Using Water Quality Index Method, vol. 5. 2013.

[23] SON, "Nigeria Standards for Drinking Water Quality," 2011.

[24] R. Brown, N. McClelland, R. Deininger, and M. O'Connor, "A water quality index crashing the physiological barrier," Indic Env. Qual, vol. 1, no. 1, pp. 173-182, 1972.

[25] M. Rajasegar, "Physicochemical characteristics of the Vellar estuary in relation to shrimp farming," J. Environ. Biol., no. 24, pp. 95-101, 2003.

[26] S.. M. D. Islam and G. Azam, "Seasonal variation of physicochemical and toxic properties in three major rivers; Shitalakhya, Buriganga and Turag around Dhaka city, Bangladesh," J. Biodivers. Environ. Sci., vol. 7, no. 3, pp. 120-131, 2015.

[27] M. Kabir et al., "Assessment of effluent quality of Dhaka export processing zone with special emphasis to the textile and dyeing industries," Jahangirnagar Univ. J. Sci., vol. 1, pp. 137-138, 2002.

[28] MPCA, "Low Dissolved Oxygen in Water- Causes, Impact on Aquatic Life - An Overview," no. February, 2009.

[29] P. R. Kannel and S. Lee, "Application of Water Quality Indices and Dissolved Oxygen as Indicators for River Water Classification and Urban Impact Assessment," Environ. Monit. Assess., vol. 132, pp. 93-110, 2007. 
[30] G. Murhekar, "Determination of Physico-chemical parameters of surface water samples in and around Akot city," Int. Res. J. Chem. Environ., vol. 1, no. 2, pp. 183-187, 2011.

[31] S. Suthar, J. Sharma, M. Chabukdhara, and A. K. Nema, "Water quality assessment of river Hindon at Ghaziabad, India: impact of industrial and urban wastewater," Environ. Monit. Assess., vol. 165, no. 1, pp. 103-112, 2010.

[32] O. Osibanjo, A. P. Daso, and A. M. Gbadebo, "The impact of industries on surface water quality of River Ona and River Alaro in Oluyole Industrial Estate, Ibadan, Nigeria," African J. Biotechnol., vol. 10, no. 4, pp. 696-702, 2011.

[33] A. A. Ayoade and O. G. Nathaniel, "Assessment of Heavy Metals Contamination of Surface Water and Sediment of a Tropical Manmade Lake Southwestern Nigeria," Int. J. Environ. Pollut. Res., vol. 6, no. 3, pp. 1-16, 2018.

[34] I. T. Tenebe, C. P. Emenike, and C. Daniel Chukwuka, "Prevalence of heavy metals and computation of its associated risk in surface water consumed in Ado-Odo Ota, South-West Nigeria," Hum. Ecol. Risk Assess. An Int. J., vol. 25, no. 4, pp. 882-904, May 2019.
[35] K. Manoj and P. Avinash, "A review of permissible limits of drinking water," Indian J. Occup. Environ. Med. Med., vol. 16, no. 1, pp. 1-6, 2012.

[36] A. A. Bordalo, R. Onrassami, and C. Dechsakulwatana, "Survival of faecal indicator bacteria in tropical estuarine waters (Bangpakong River, Thailand)," J. Appl. Microbiol., vol. 93, pp. 864-871, 2002.

[37] M. A. Nkansah, N. O. Boadi, and M. Badu, "Assessment of the quality of water from hand-dug wells in ghana.," Environ. Health Insights, vol. 4, pp. 7-12, Apr. 2010.

[38] A. Kumar and A. Dua, "Water Quality Index for Assessment of Water Quality of River Ravi at Madhopur (India)," Glob. J. Environ. Sci., vol. 8, no. 1, pp. 49-57, 2009.

[39] E. E. Etim, R. Odoh, A. U. Itodo, S. D. Umoh, and U. Lawal, "Water Quality Index for the Assessment of Water Quality from Different Sources in the Niger Delta Region of Nigeria," Frontiers Sci., vol. 3, no. 3, pp. 89-95, 2013. 